\title{
KEBERHASILAN EBAY DALAM SITUS PELELANGAN DI KALANGAN INTERNATIONAL
}

\author{
M.Agus Setiawan \\ 165100112 \\ Fakultas Komputer \\ agussetiawan.student@umitra.ac.id
}

\begin{abstract}
Abstrack
Penulisan bertujuan untuk mengetahui keberhasilan eBay sebagai situs pelelangan dikalangan International . eBay adalah sebuah situs lelang di seluruh dunia yang didirikan oleh Pierre Omidyar pada 3 September, 1995 di San Jose, CA. Ia awalnya bernama AuctionWeb dan merupakan bagian dari situs pribadi yang lebih besar. Item pertama yang dijual di situs oleh Omidyar adalahlaser pointer rusak, untuk seorang kolektor yang rusak laser pointer. Nama perusahaan telah diubah oficially ke eBay pada bulan September, 1997. Penulis menggunakan metode deskriptif, yaitu suatu metode yang menyimpulkan, menyajikan, dan menganalisis data sehingga menghasilkan gambaran yang cukup jelas atas penulisan ini. Hasil penelitian menunjukkan bahwa eBay mampu berkembang hingga saat ini karena berhasil menumbuhkan kepercayaan dari konsumennya dan mampu membangun interaksi yang baik antar penjual dan pembeli dengan melakukan perluasan usahanya dengan akuisisi Skype dan video. eBay mendorong pertumbuhannya saat ini dengan mengadopsi aplikasi mobile, mengintegrasikan dengan iPhone, dan menggalang kepedulian terhadap lingkungan.
\end{abstract}

Kata Kunci : Produk Terlengkap dan Terpercaya 
Fakultas Komputer

\section{TUGAS 1 - 88675543}

\section{PENDAHULUAN}

eBay, mulanya adalah situs untuk orang-orang yang membosankan, baru berhenti darikerja, para ibu rumah tangga yang serikat di rumah, dan para pensiunan yang bosan, untuk menjual berbagai barang aneh. Tapi, eBay dengan cepat tumbuh menjadi pasar ramai senilai 30 juta, dengan hukum dan normanya sendiri. Bahkan, eBay memiliki sistem pembayaran yangdinamai PayPal: sistem pembayaran yang memungkinkan pelanggan untuk melakukan pembayaran elektronik ke para penjual di eBay yang tidak memiliki rekening kartu kredit. Di eBay, banyak sekali dijumpai perusahaan perusahaan besar yang ikut'bermain', diantaranya Sears Roebuck, Home Depot, Walt Disney, bahkan IBM. Lebih dari seperempat penawaranterdaftar dengan harga tetap. Jadi, apa yang dahulu dimulai sebagai pasar lelang murni bagi pelanggan, kini juga menjadi basar B2C (Business to Consumer) dan bahkan B2B (Business toBusiness) yang penghasilannya mencatat laba bagi para pemegang saham eBay.

Sejalan dengan perluasan ekonomi, CEO eBay, Meg Whitman dan timnya mendapati bahwa mengelola situs itu dapat menjadi jauh lebih sulit, terutama karena jutaan pemakai eBayyang sangat bernafsu dan menuntut suara dalam semua keputusan. Proses ini terjadi di
M.Agus setiawan

Setiap beberapa bulan, para eksekutif eBay bertemu dengan lusinan penjual dan pembeli, terutama 'best seller', untuk mengajukan berbagai pertanyaan mengenai bagaimana mereka bekerja dan hal lain apa yang harus dilakukan. Hasilnya, para pemakai merasa seperti pemilik, dan mereka berinisiatif untuk memperluas ekonomi. Contoh, toko alat mesin ReliableTools Inc, mencoba mendaftarkan beberapa barang di eBay pada akhir tahun 1998, dan ternyata barang mereka sangat laris, menghasilkan omset $\$ 1$ juta lebih per bulannya.

Program lain dari eBay adalah eBay Motors. Program ini dibuat manajer eBay saat itu,Simon Rothman, awal 1999. Dia paham situasinya berbeda dengan pasar pada umumnya,sehingga mereka langsung membeli perusahaan lelang mobil koleksi, Kruse International, seharga \$150 juta untuk persediaannya. Pendekatan ini ternyata berjalan dengan baik. Penjualan mobil dan suku cadangnya, senilai \$5 milyar, yang disertai kenaikan tahunan, adalah pasar eBay terbesar

\section{Indentifikasi Masalah}

Berdasarkan latar belakang yang telah dijelaskan, dapat di indentifikasi masalah sebagai berikut:

$\begin{array}{ccc}\text { 1.Bagaimana strategi yang digunakan } \\ \text { eBay } & \text { sehingga } & \text { mengalami } \\ \text { keberhasilan dikalangan International? }\end{array}$


Fakultas Komputer

\section{TUGAS 1 - 88675543}

\section{Tujuan Penelitian}

Bertujuan untuk menguji penerapan eBay dalam kehidupan sehari-hari.

\section{Manfaat Penelitian}

Dapat memberi suatu keberhasilan eBay sebagai situs pelelangan dikalangan International.

\section{Metode Penelitian}

Penelitian merupakan suatu proses dengan langkah-langkah yang dilaksanakan secara sistematis guna mendapatkan pemecahan masalah atau mendapatkan jawaban terhadap setiap permasalahan yang ada. Setiap penelitian memerlukan adanya metodologi untuk memperlancar penelitian dalam rangka pencarian data dan petunjuk mengenai cara atau langkah serta teknik penelitian.

Metode penelitian merupakan suatu cara kerja untuk dapat memahami obyek penelitian yang menjadi sasaran penelitian. ( Marzuki, 1995)

Penelitian ini menggunakan metode deskriptif, yaitu suatu metode yang menyimpulkan, menyajikan, dan menganalisis data sehingga menghasilkan gambaran yang cukup jelas atas penulisan ini.

\section{Pengertian eBay}

eBay adalah sebuah situs lelang di seluruh dunia yang didirikan oleh Pierre
M.Agus setiawan

Omidyar pada 3 September, 1995 di San Jose, CA. Ia awalnya bernama AuctionWeb dan merupakan bagian dari situs pribadi yang lebih besar. Item pertama yang dijual di situs oleh Omidyar adalahlaser pointer rusak, untuk seorang kolektor yang rusak laser pointer. Nama perusahaan telahdiubah oficially ke eBay pada bulan September, 1997. Pergi perusahaan publik pada tahun 1998,dan membuat Omidyar pertama presiden eBay, Jeff Skoll, instant billionaires. Perusahaan telahdibeli banyak perusahaan terkait lainnya, termasuk PayPal, Skype dan persentase bunga dicraigslist. Seperti ini menulis mereka mempekerjakan lebih dari 12.000 karyawan di seluruhdunia, dan berkantor pusat di SanJose, CA.

\section{Rahasia sukses eBay}

Marktplaats.nl, platform E-commerce terbesar di Belanda yang juga merupakan anak perusahaan eBay sejak 2004, tengah mengembangkan bisnisnya dengan menggunakan layanan berlangganan MySQL Enterprise Unlimited database dari Sun Microsystems. Untuk memastikan pertumbuhan perusahaan yang cepat, perlindungan site uptime dan menekan biaya TI, perusahaan saat ini menggunakan infrastruktur berbasis teknologi open source yang fleksibel seperti MySQL yang didukung oleh tim pendukung database global Sun Microsystems yang selalu siaga selama 7 hari 24 jam. 
Fakultas Komputer

\section{TUGAS 1 - 88675543}

Ketika para pendiri Marktplaats.nl memiliki ambisi yang besar untuk bisnis mereka yang berdiri pada tahun 1999, mereka juga memiliki keterbatasan dana. Mereka membutuhkan infrastruktur yang menawarkan potensi berkembang baik secara teknis maupun menghemat biaya untuk mendukung pertumbuhan masa depan.

Untuk menyediakan layanan online yang fleksibel dengan biaya operasional yang terbatas, para pendiri Marktplaats.nl memilih software LAMP open source yang popular (Linux, Apache, MySQL, PHP/Perl/Python). MySQL terbukti mampu memberikan nilai tambah untuk mendukung pertumbuhan situs mereka yang didukung oleh kehandalan dan kinerja yang tinggi serta kemudahan penggunaan. Dalam waktu singkat, tim ini mampu mengelola database server baru, mengembangkannya serta memelihara database server lama. "Skalabilitas sungguh menjadi kunci kesuksesan kami," kata Bas Anneveld, Site Operations Manager Marktplaats.nl. "MySQL merupakan database yang sempurna untuk bisnis yang tengah berkembang cepat dan membutuhkan peningkatan infrastruktur secepat mungkin namun hemat biaya untuk memenuhi kebutuhan."

Marktplaats.nl pada awalnya bergantung pada MySQL Community Edition dan dukungan self-support dari komunitas MySQL, perusahaan kemudian dengan cepat mencapai
M.Agus setiawan

tingkat dimana dukungan yang tepat setiap saat dibutuhkan.

Marktplaats.nl kemudian berlangganan layanan MySQL Enterprise Unlimited yang memungkinkan perusahaan untuk memperoleh MySQL software update, perangkat monitoring dan dukungan teknis untuk database server yang tidak terbatas dengan biaya yang terjangkau setiap tahunnya. Kemudian lanjut Anneveld, "Dengan harga setara sebuah CPU Oracle Enterprise Edition (seharga EUR 32.000, GBP 24.000, US\$ 40.000), perusahaan dapat secara otomatis menggunakan dan memonitor sendiri server MySQL Enterprise dalam jumlah tak terbatas dengan dukungan penuh selama 7 hari 24 jam."

\section{Sistem pembayaran di eBay}

Sistem pembayaran di ebay menggunakan Paypal, kenapa paypal? Karena sistem pembayaran ini dinilai lebih aman bagi para pembeli dan penjual dan sangat cocok untuk pembayaran lelang, krena pemegang akun paypal akan diverivikasi oleh pihak paypal sehingga kemungkinan penipuan berkurang. Namun di ebay terdapat cara pembayaran lain sepertiegold, moneybooker, western union, cek, transfer bank, dan tunai. Biaya pengiriman akan dibebankan kepada pembeli dengan syarat dan kondisi serta perjanjian sebelumnya antara pihak penjual dan pembeli baik pengiriman barang domestik maupun international. 
Fakultas Komputer

TUGAS 1 - 88675543

\section{Cara kerja Ebay}

Dalam pasar online ebay anda tidak perlu untuk mendaftar untuk melihat barang-barang yang anda cari atau yang terjual di ebay, tetapi untuk melakukan pembelian atau penjualan anda harus mendaftar. Cara melakukan registrasi akun di ebay adalah anda akan disuruh untuk memasaukan informasi seperti nama, email, dan membuat password untuk akun anda. Setelah itu anda akan mendapatkan ID pengguna ebay yang berfungsi untuk transaksi dan proses yang ada di dalam ebay, jika anda telah menyelesaikan proses registrasi akun/ sign up maka anda sudah dapat bertransaksi dipasar online ebay. Sebelum memulai berdagang di ebay ada beberapa instrument pendukung yang akan mendukung kelancaran berbisnis anda di eBay sebagai berikut:

1. Account paypal yang sudah di verivikasi, baik menggunakan vcc ataupun menggunakan credit card pribadi

2. Tentu saja mendaftar account ebay dengan alamat lengkap asli dan akurat. Bay Selling Manager

3. Turbolister, Auctiva, dan template untuk melisting barang jualan anda

4. Sniper bid.

5. eBay selling calculator

6. Auto response email, autoreply etc.

7. Account bank di indonesia untuk widthdraw uang dari paypal
M.Agus setiawan

8. Cari feedback dan track record yang baik

9. Currrency converter

4. Potensi ke Depan

\section{Strategi ilmu teknologi e_bay}

eBay mempertahankan sejumlah situs khusus. EBay Pulse, misalnya, memberikan informasi tentang istilah pencarian populer, tren, dan item yang paling banyak ditonton. Ebay Terdapat konten ebay Komunitas lain termasuk Discussion Boards, Groups, Answer Center, Chat Rooms, and Reviews \& Guides . eBay memiliki penawaran mobile yang kuat, termasuk SMS alert, situs WAP, Java ME client,dan aplikasi iPhone Apple tersedia di pasar tertentu.

Keunggulan ebay.com adalah disini barang yang dijual dapat dibeli dengan harga yang lebih murah, disebabkan situs ini merupakan situs lelang. Kebanyakan barang yang dijual merupakan barang bekas, sehingga harga yang ditawarkan lebih murah dibandingkan dengan online store lainnya.

\section{Strategi tingkat Corporate (perusahaan)}

1. Penetrasi Pasar.

Usaha meningkatkan pangsa pasar yang sudah ada saat ini dengan upaya pemasaran yang lebih besar. Upaya tersebut meningkatkan jumlah tenaga penjualan, meningkatkan jumlah belanja iklan, meningkatkan promosi 
Fakultas Komputer

TUGAS 1 - 88675543

penjualan secara ekstensif, meningkatkan publisitas. Meningkatkan pangsa pasar eBay.com ini bisa dilihat dari meningkatnya penjualan tahun $2002 \$ 3,93$ milyar, bila kita lihat pada tahun 2003 meningkat jadi $\$ 5,26$ milyar. Hal ini bisa terjadi karena eBay.com menjual banyak produk dan banyak pula pasamya. Tidak terbatas di AS saja. Walaupun sudah banyak produk sejenis di pasar yang akan dituju, walaupun tahu bahwa disitu sudah banyak pesaingnya tetapi eBay.com tetap akan masuk ke pasar tersebut. Contoh bookstore di Inggris sudah ada, di Jerman sudah ada, di Prancis juga sudah ada, tetapi eBay.com tetap masuk ke pasar tersebut bahkan berhasil merebut saham-saham perusahaan tersebut.

\section{Pengembangan Pasar.}

Memperkenalkan produk yang sudah ada ke daerah (geografi) baru. Dalam hal ini eBay.com tidak hanya beroperasi di wilayah AS tetapi sudah ke Eropa antara lain: Jerman, Inggris, Prancis dan ke Amerika Utara (Kanada). Akhirakhir ini ekspansi dilakukan ke Asia Pasifik dan ke Amerika Latin, bahkan ke depan e-bay ingin menguasai Asia dan Afrika.

\section{Pengembangan Produk.}

Upaya peningkatan penjualan dengan memperbaiki dan memodifikasi produk atau jasa. eBay.com juga melakukan pengembangan produk contohnya: eBay.com travel menjual jasa
M.Agus setiawan

transportasi dan Virginmega.com yaitu penjualan berbagai macam produkproduk kantor. Serta eBay.com.sport menjual berbagai alat olahraga.

\section{Diversifikasi konsentrik (terfokus).}

Menambah produk atau jasa baru, tetapi berhubungan dengan usaha inti. Contoh eBay.com.inc. menjual PC melalui toko online-nya. Daripada disimpan di gudang. eBay.com cukup mengirimkan pesanan komputer ke penjual grosir ingram micro, yang mengemas dan mengirimkan adalah Ingram micro. Transaksinya via eBay.com. Jadi disini eBay.com dapat meminimalkan operasionalnya dengan tetap memperoleh keuntungan tanpa harus beresiko.

\section{Diversifikasi Horizontal.}

Menambah produk atau jasa baru, tetapi tidak ada hubungan dengan bisnis inti.Contohnya eBay.com menjual produk alat-alat perkantoran.

6. Integrasi kedepan (Forward).

Akuisisi kepemilikan untuk peningkatan kontrol atas distributor atau pengecer. Yang sudah diimplementasikan eBay.com adalah dengan membeli beberapa perusahaan dan beberapa website yang kemudian untuk digabungkan ke dalam kontrol eBay.com. beberapa contoh:

a. Britsh bookstore (lnggris) menjadi eBay.co.uk. 
Fakultas Komputer

\section{TUGAS 1 - 88675543}

b. Telebuch inc. bookstore online (Jerman) menjadi amzon.cu.de.

c. Pets.com. $(50 \%)$

d. Sotheby $(1,7 \%)$ lelang online menjadi Sotheby-eBay.com.

e. Acquire e-Nische inc.

f. Accepl.com

g. Alexaintemet.co.

h. HomeGrocer.com(35\%)

i. Gear.com (49\%)

7. Integrasi ke belakang (Backward).

Akuisisi kepemilikan untuk meningkatkan kontrol atas pemasok. Beberapa contohnya

adalah:

a. e-British bookstore.

b. Telebuch inc. bookstore.

c. Bookstore eBay. fro (Prancis)

d. Babies RUS \{Produk bayi\}

e. Toys RUS (Produk mainan anak-anak)

\section{Kekurangan e-bay}

Berikut adalah kekuragan dari eBay:

1. Karyawannya $30 \%$ orang lama. 30 $\%$ orang baru, $40 \%$ rekrut acak.

2. Para Eksekutif direkrut dari perusahaan yang sudah terkenal yaitu Wall-Mart, Microsoft,Barnes \&Noble, dan Symantec. Yang dinilai punya kemampuan tinggi.

3. Ada 57 merk terkenal di dunia yang bisa diakses di eBay.com.

4. Ada diskon harga pada beberapa produk.

5. Beban pemasaran pada jaringan pemasaran bersama mengalami
M.Agus setiawan

penurunan dari penjualan bersih pada Januari 2003.

6. Biaya iklan berkurang karena pakai jaringan online.

7. Dapat menyediakan kebutuhan sehari-hari pelanggan dengan murah, cepat, bermutu.

8. Bebas biaya pengiriman untuk order berkualitas.

9. Dapat membantu perusahaan lain untuk menawarkan produk dan jasanyadi websiteeBay.com.

10. Pelayanan cepat pada order pasti dan prioritas berikutnya pada order meragukan.

11. Memberi hadiah di tingkat pusat pelayanan pelanggan.

12. Telah mengembangkan teknologi "I-Click" otomatis (Panggil klik pelanggan perorangan).

13. Telah meluncurkan eBay Friends \& Favorite (Tolong menolong sesama pelanggan untuk menemukan produk dan jasa di eBay.com).

14. Punya indeks kepuasan pelanggan dengan skore 88 .

15. Punya program rekanan yang sudah terdaftar sebanyak 530.000 web.

16. eBay.com telah berinvestasi cukup besar pada pusat distribusi otomatis di dalam

dan diluar Amerika Serikat. Punya infrastruktur cepat, canggih, kompetitif.

\section{Peluang e-bay}

Ebay memilik Bisnis bebas pajak sejak 1998. Kebijakan Presiden Bush tentang penangguhan beban pajak atas transaksi di Internet Sampaidengan Nopember 
Fakultas Komputer

\section{TUGAS 1 - 88675543}

2003. Pertumbuhan yang pesat pengguna atau pemakai baru internet di Asia Pasifik, Amerika Latin,dan Eropa. Pada akhir 2005 meningkat dua kali lipat yaitu 1,12 milyar pengguna.Tingkat pendapatan masyarakat di wilayah Asia Pasifik, Amerika Latin, dan Eropa Baratmeningkat. Pengguna internet 77 $\%$ kulit putih, sisanya jadi peluang di Asia Pasifik, Amerika Latin danAfrika. Pengguna internet terbesar umur 30 - 49 tahun sebesar $47 \%$, berarti masih ada peluang besar di luar kriteria umur tersebut. Pengguna internet terbesar adalah masyarakat perkotaan lebih kurang $42 \%$. Masih ada peluang pasar untuk masyarakat pinggiran dan pedesaan. Teknologi komputer dan internet terus diperbaiki dan berkembang sehingga akses lebih cepatdan lebih luas jangkauannya. Ada peningkatan penggunaan kartu kredit online. Inovasi baru berupa pengalaman berbelanja via internet.

\section{Keberhasilan eBay dalam situs pelelangan international}

Keberhasilan eBay dimulai dengan menciptakan sebuah "revolusi harga" yang memungkinkan penawar / pembeli untuk menentukan harga yang mereka inginkan dalam membeli sebuah item. Para konsumen senang karena mereka merasa memegang kendalidan mendapatkan harga terbaik. Para penjual juga senang karena mereka mampu
M.Agus setiawan

mencapai berbagai segmentasi pembeli dan hanya perlu mengeluarkan overhead yang sangat kecil saat transaksi dilakukan.

Alasan eBay berhasil sementara yang lain gagal karena bisnis lain tidak dapat menciptakan model bisnis yang unik sekaligus menyenangkan dari sisi pembeli dan penjual. Meskipun eBay hanya memiliki sedikit pemasukan pendapatan, tetapi ia tidak perlu bergabung dengan perusahaan perusahaan lain seperti: auction.com, sandcrawler.com, dan firstauction.com.

Keberhasilan eBay juga didapat karena faktor - faktor lain sebagai berikut:

- Alamat web yang mudah diingat

- Situs yang mudah dinavigasi

- Mudahnya interaksi antara pembeli dan penjual

\section{Perkembangan pertumbuhan eBay}

Di bawah kepemimpinan baru, perusahaan akan terus fokus pada salah satu keyakinan pendirinya yaitu komitmen yang kuat dan investasi dalam teknologi yang membantu orang untuk saling terhubung (antara penjual dan pembeli). Upaya terakhir yang telah dilakukan eBay adalahmengadopsi aplikasi mobile, mengintegrasikan dengan iPhone, dan menggalang kepedulian terhadap lingkungan yang telah membantu membawa perusahaan eBay ke puncak kesuksesan. eBay memberikan kesempatan kepada jutaan pengguna dalam memberikan 
Fakultas Komputer

\section{TUGAS 1 - 88675543}

suara guna pengambilan keputusan penting perusahaan melalui suara dari program Nasabah. Setiap beberapa bulan, eBay membawa sekitar 12 penjual dan pembeli dan meminta mereka untuk memberikan penilaian tentang bagaimana eBay bekerja dan apa lagi yang perlu eBay lakukan. Setidaknya, dua kali seminggu perusahaan memegang telekonferensi untuk menyediakan pendapat bagi pengguna di hampir setiap fitur baru dan kebijakan. Hasilnya, pelanggan eBay merasa seperti pemilik, dan dengan demikian eBay mampu mengambil inisiatif untuk memperluas perusahaan ke wilayah yang selalu baru. eBay terus memperluas kemampuannya untuk membangun minat masyarakat dan orang-orang yang terhubung di seluruh dunia dengan menambahkan jasa, kemitraan, dan investasi.

EBay memulai perkembangannya dengan membangun kepercayaan konsumen yang merupakan elemen kunci keberhasilannya melalui jejaring social online, twitter dan facebook. Selain itu, eBay melakukan salah satu penambahan jasa yaitu dengan akuisisi PayPal. Hal ini ditujukkan untuk memudahkan pelanggan atas layanan pembayaran melalui online. PayPal adalah metode pembayaran yang disukai oleh banyak kalangan. Akuisisi ini dilakukan untuk memungkinkan pedagang agar dengan mudah menjual produk di seluruh dunia.selain itu, eBay juga mengakuisisi Skype dan jasa komunikasi vidio untuk membantu
M.Agus setiawan

membangkitkan minat penjual dan pembeli dalam perusahaan. Pembeli dan penjual berkomunikasi melalui suara atau video secara gratis dan hal tersebut menghasilkan tambahan pendapatan iklan untuk eBay.

\section{Kesimpulan}

eBay sebagai perusahaan yang bergerak di bidang bisnis online telah mampu menarik berbagai segmen penjual dan meraih pasar dalam bisnisnya. Hal ini didukung dengan penerapan strategi harga yang baik berupa model lelang. Strategi tersebut mampu mengakomodasi keinginan baik dari sisi penjual maupun pembeli.

eBay mampu berkembang hingga saat ini karena berhasil menumbuhkan kepercayaan dari konsumennya dan mampu membangun interaksi yang baik antar penjual dan pembeli dengan melakukan perluasan usahanya dengan akuisisi Skype dan video. eBay mendorong pertumbuhannya saat ini dengan mengadopsi aplikasi mobile, mengintegrasikan dengan iPhone, dan menggalang kepedulian terhadap lingkungan. Semua hal tersebut membuat eBay mampu meraih kesuksesan.

\section{Daftar Pustaka}

Stambuk,Sovi (2019, 24 April). Sukses dalam implentasi eBay. 


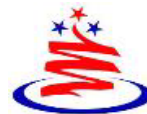

Fakultas Komputer

M.Agus setiawan

TUGAS 1 - 88675543

https://www.academia.edu/28849529/Makal

ah_-ebay

Fauzy, Ahmad ( 2014, 12 September). Jenis

dan contoh e-commerce.

http://ahmadfauzy.web.ugm.ac.id/2014/12/0

9/jenis-jenis-dan-contoh-e-commerce/ 